RACIC 5 (1) (2020)
JNIVERSITAS
ABDURRAB

\title{
ANALISIS BALIK KUAT GESER TANAH TERSTABILISASI SEMEN DENGAN METODE NUMERIK
}

\author{
Muhammad Toyep ${ }^{1}$ Husni Mubarak ${ }^{2}$ \\ ${ }^{1,2}$ Program Studi Teknik Sipil Universitas Abdurrab \\ Jl. Riau Ujung No.73, Pekanbaru, Indonesia \\ email :mtoyep@univrab.ac.id \\ email : husni.mubarak@univrab.ac.id
}

\begin{tabular}{l}
\hline Info Artikel \\
\hline Sejarah Artikel: \\
Diterima Juni 2020 \\
Disetujui Juni 2020 \\
Dipublikasikan Juni 2020 \\
\hline
\end{tabular}

Keywords : Triaksial UU, Tekan bebas, Tegangan dan Regangan, Plaxis 2D

\begin{abstract}
Abstrak
Kuat geser tanah merupakan suatu parameter penting di dalam analisis kekuatan tanah. Kuat geser diperoleh dari uji laboratorium yang diinterpretasikan sebagai tegangan regangan. Pengujian dilakukan pada tanah terstabilisasi semen dengan kadar semen 5\%; 10\%; 15\%. Pengujian dilakukan dengan alat uji triaksial takterkonsolidasi takterdrainase (triaksial UU) pada tekanan sel 50;100; $200 \mathrm{kN} / \mathrm{m} 2$ dan uji tekan bebas. Benda uji merupakan contoh tanah terganggu yang dipadatkan dan dibentuk kembali, lalu dilakukan pemeraman selama $0 ; 3 ; 7 ; 14 ; 28$ hari. Tegangan regangan hasil pengujian laboratorium kemudian dianalisis balik dengan metode numerik pada program Plaxis 2D yang menggunakan model Mohr-Coulumb dan Hardening Soil. Analisis menunjukkan model Hardening Soil dan Mohr-Coulumb memberikan hasil tegangan puncak yang mendekati sama dengan hasil pengujian triaksial UU dan tekan bebas. Khusus untuk regangan dengan model Mohr-Coulumb, memberikan hasil regangan yang lebih kecil dari pengujian triaksial UU dan tekan bebas. Dengan model Hardening Soil, memberikan hasil regangan yang fluktuatif dari pengujian triaksial UU karena dipengaruhi oleh penerapan tekanan sel $(\sigma 3)$ dan memberikan hasil regangan yang lebih besar dari pengujian tekan bebas.
\end{abstract}

Kata Kunci: Triaksial UU, Tekan bebas, Tegangan dan Regangan, Plaxis 2D 
affected by the application of cell pressure ( $\sigma 3)$ and it provides greater strain results from unconfined compression test.

Keywords: Triaxial UU, Unconfined Compresssion, Stress and Strain, Plaxis $2 D$

(C) 2020 Universitas Abdurrab

Alamat korespondensi:

J1. Riau Ujung No.73,

Pekanbaru, Indonesia

email : mtoyep@univrab.ac.id

ISSN 2527-7073

\section{PENDAHULUAN}

Tanah hasil galian biasanya menjadi tanah terganggu, yang pada umumnya berubah sifat menjadi tidak padat dan lepas, tegangan geser yang lemah, dan kuat dukung yang rendah. Kondisi ini merupakan sifat teknis yang buruk pada tanah karena tanah tidak memiliki daya ikat yang cukup kuat untuk mempertahankan kedudukan antar butir-butirnya, yang berakibat sering terjadi kegagalan dari fungsi tanah tersebut apabila menerima beban. Oleh karena itu perlu dilakukan suatu usaha stabilisasi tanah untuk memperbaiki sifat-sifat yang buruk pada tanah dengan tambahan campuran bahan semen untuk beberapa variasi kadar semen.

Maksud dari penelitian adalah untuk melihat seberapa besar kenaikan kekuatan tanah terstabilisasi semen yang ditinjau dalam bentuk kurva tegangan regangan. Adapun tujuan penelitian adalah untuk mengetahui perbandingan antara tegangan regangan hasil pengujian laboratorium dengan analisis metode numerik.

Penelitian ini dilakukan dalam skala uji laboratorium menggunakan alat uji triaksial cara unconsolidated undrained (UU) dan alat uji kuat tekan bebas. Selanjutnya, data masukan pada percobaan uji laboratorium akan dianalisis balik menggunakan program Plaxis2D dengan model tanah Mohr-Coulumb dan Hardening Soil.

(Tarigan, R., 2012), telah melakukan penelitian tentang karakteristik kuat geser tanah lempung dari uji kuat tekan bebas dan uji triaksial (UU). Prediksi balik dalam program Plaxis2D dengan model tanah soft soil menghasilkan tegangan deviator yang hampir sama dengan hasil uji laboratorium dan cocok untuk jenis tanah Pulau Sicanang.

\section{TINJAUAN PUSTAKA}

\section{Kuat Geser}

Kuat geser tanah adalah gaya perlawanan yang dilakukan oleh butir-butir tanah terhadap desakan atau tarikan (Hardiyatmo, H. C., 2012). Kuat geser tanah diukur dengan dua parameter tanah yaitu kohesi (c) dan sudut geser $(\varphi)$. Bila kedudukan tegangan-regangan digambarkan dalam koordinat-koordinat $\mathrm{p}-\mathrm{q}$, dengan: 


$$
\begin{aligned}
& p=1 / 2\left(\sigma_{1}{ }^{\prime}+\sigma_{3}{ }^{\prime}\right) \\
& q=1 / 2\left(\sigma_{1}{ }^{\prime}-\sigma_{3}{ }^{\prime}\right)
\end{aligned}
$$

Sembarang kedudukan tegangan dapat ditunjukkan oleh sebuah titik tegangan sebagai ganti dari lingkaran Mohr pada Gambar 1.

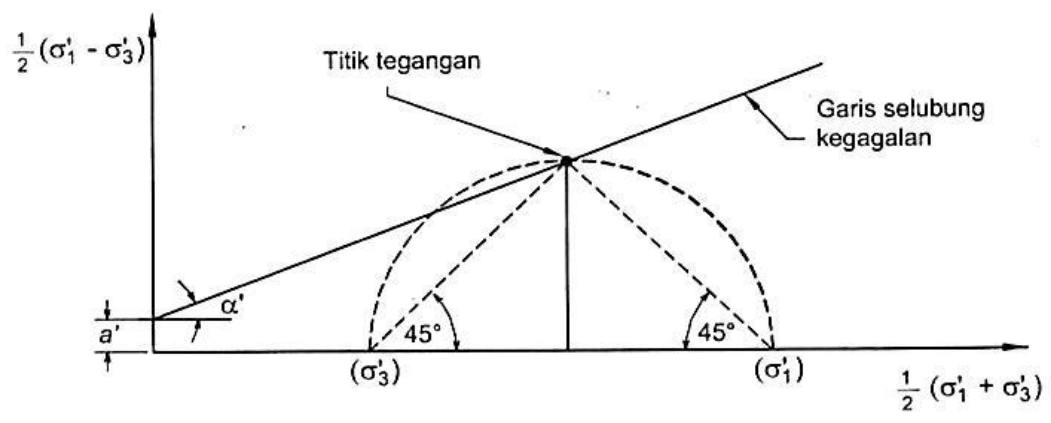

Gambar 1. Kondisi tegangan yang mewakili [1]

Pada Gambar 1, garis selubung kegagalan ditunjukkan oleh persamaan:

$$
\frac{1}{2}\left(\sigma_{1}{ }^{\prime}-\sigma_{3}{ }^{\prime}\right)=a^{\prime}+1 / 2\left(\sigma_{1}{ }^{\prime}+\sigma_{3}{ }^{\prime}\right) \operatorname{tg} \alpha^{\prime}
$$

dengan a' dan $\alpha$ ' adalah parameter modifikasi dari kuat gesernya. Parameter c' dan $\varphi$ ' diperoleh dari persamaan:

$$
\begin{aligned}
& \varphi^{\prime}=\arcsin \left(\operatorname{tg} \alpha^{\prime}\right) \\
& c^{\prime}=\frac{a^{\prime}}{\cos \varphi^{\prime}}
\end{aligned}
$$

\section{Uji Triaksial}

Diagram skematik dari alat triaksial dapat dilihat pada Gambar 2. Pada pengujian ini, dapat digunakan tanah benda uji dengan diameter kira-kira 3,81 cm dan tinggi 7,62 cm. Benda uji dimasukkan dalam selubung karet tipis dan diletakkan kedalam tabung kaca. Biasanya, ruang didalam tabung diisi dengan air atau udara. Benda uji ditekan oleh tekanan sel, yang berasal dari tekanan cairan di dalam tabung. Udara kadang-kadang dapat digunakan sebagai media untuk penerapan tekanan selnya (tekanan kekang atau confining pressure). Alat pengujian dihubungkan dengan pengatur drainase ke dalam maupun ke luar dari benda uji. Untuk menghasilkan kegagalan geser pada benda uji, gaya aksial dikerjakan melalui bagian atas benda uji. 


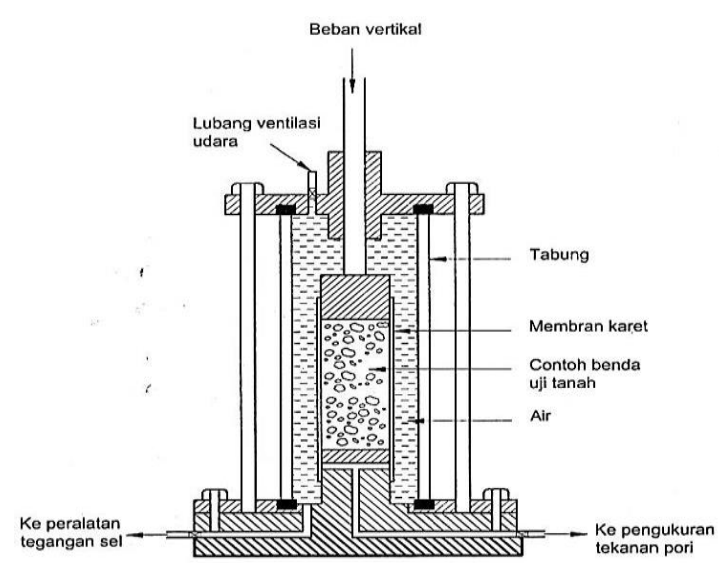

Gambar 2. Skema Alat uji triaksial

Uji triaksial dapat dilaksanakan dengan tiga cara, yaitu:

1. Unconsolidated-Undrained (UU)

2. Consolidated-Undrained (CU)

3. Consolidated-Drained (CD)

\section{Uji Tekan Bebas}

Gambar skematik dari prinsip pembebanan dalam percobaan ini dapat dilihat pada Gambar 3. Kondisi pembebanan sama dengan yang terjadi pada uji triaksial, hanya tekanan selnya nol .

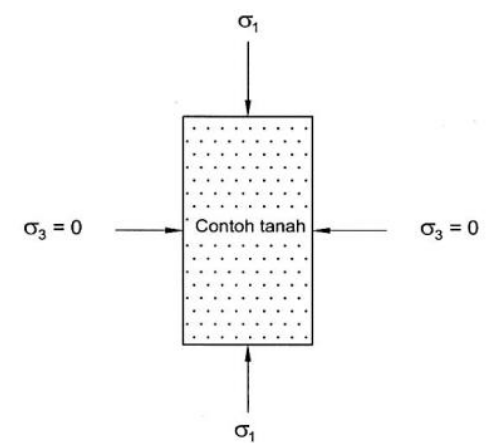

Gambar 3. Skema uji tekan bebas

Tegangan aksial yang diterapkan di atas benda uji berangsur-angsur ditambah sampai benda uji mengalami keruntuhan. Pada saat keruntuhannya, karena $\left(\sigma_{3}=0\right)$, maka:

$$
\sigma_{1}=\sigma_{3}+\Delta \sigma_{\mathrm{f}}=q_{\mathrm{u}}
$$

dengan, $q_{u}=$ kuat tekan bebas; $\sigma_{1}=$ tegangan utama mayor; $\sigma_{3}=$ tegangan utama minor; = tegangan deviator pada saat keruntuhan terjadi. Secara teoritis, nilai pada lempung jenuh seharusnya sama seperti yang diperoleh dari pengujian-pengujian triaksial UU dengan benda uji yang sama. Jadi,

$$
s_{u}=c_{u}=\frac{q_{u}}{2}
$$


dengan, $s_{u}=c_{u}=$ kuat geser undarined.

\section{Program Plaxis2D}

Plaxis adalah program komputer berdasarkan elemen hingga dua-dimensi yang digunakan secara khusus untuk melakukan analisis deformasi dan stabilitas untuk berbagai aplikasi dalam bidang geoteknik. Program ini terdiri dari empat buah sub-program yaitu: masukan, perhitungan, keluaran dan kurva. Model material yang digunakan untuk analisis tegangan- regangan pada tanah dalam penelitian ini ada 2 (dua jenis), yaitu:

\section{a. Model Mohr-Coulomb}

Parameter yang diperlukan untuk model Mohr-Coulomb pada program Plaxis adalah kohesi $(c)$, sudut geser $(\varphi)$, sudut dilatansi $(\psi)$, modulus elastisitas Young's $(E)$ dan Poisson ratio $(v)$.

\section{b. Model Hardening Soil}

Model Hardening Soil merupakan model tingkat lanjut untuk memodelkan perilaku dari berbagai jenis tanah, baik untuk tanah lunak maupun tanah yang keras (Schanz,T., 2004). Beberapa parameter dari model Hardening sama dengan model Mohr-Coulumb yaitu kohesi (c), sudut gesek $(\varphi)$ dan sudut dilatansi $(\psi)$.

Parameter dasar untuk model Hardening Soil adalah kekakuan sekan dari uji triaksial terdrainase $\left(E_{50}^{r e f}\right)$, kekakuan tangensial untuk pembebanan primer $\left(E_{\text {oed }}^{\text {ref }}\right)$, eksponen $(m)$, kekakuan untuk pengurangan/ pembebanan kembali ( $E_{u r}^{r e f}$ ), angka Poisson untuk pengurangan/ pembebanan kembali $\left(v_{u r}\right)$.

Perilaku mekanis dari tanah dapat dimodelkan pada berbagai tingkat akurasi. Ada 3 (tiga) jenis material pada program Plaxis2D yang bisa dipilih untuk masing-masing model tanah yang digunakan, yaitu:

1. Jenis material drained

2. Jenis material undrained

3. Jenis material non-porous

\section{METODE}

Benda uji triaksial dan tekan bebas dibentuk dengan ukuran diameter 3,6 cm dan tinggi 7,2 $\mathrm{cm}$. Langkah-langkah penelitian diuraikan sebagai berikut:

\section{Persiapan benda uji}


Benda uji disiapkan berupa tanah yang lolos saringan no.10 $(2,0 \mathrm{~mm})$ dan dicampur semen dengan variasi kadar 0\%, 5\%, 10\%, 15\%. Kemudian benda uji dicetak ulang dan diperam selama $0 ; 3 ; 7 ; 14 ; 28$ hari.

\section{Pengujian laboratorium}

Benda uji yang sudah disiapkan, lalu dilakukan pengujian triaksial UU dan tekan bebas menurut lama pemeraman. Pengujian triaksial UU diberi tekanan sel $\left(\sigma_{3}\right) 50 ; 100 ; 200 \mathrm{kN} / \mathrm{m}^{2}$.

\section{HASIL}

Hasil Pengujian Sifat-sifat Fisik Tanah Asli (index properties)

Dari keseluruhan rangkaian pemeriksaan sifat-sifat fisik tanah asli, maka dapat dilihat pada Tabel 1.

Tabel 1. Hasil pengujian sifat-sifat fisik tanah asli

\begin{tabular}{lll}
\hline No & Pengujian & Nilai \\
\hline 1 & Kadar air, $w(\%)$ & 21,24 \\
2 & Berat spesifik $(G s)$ & 2,68 \\
3 & Butir tertahan saringan no. 200 (\%) & 67,13 \\
& Butir lolos saringan no. 200 (\%) & 32,87 \\
4 & Pemeriksaan grafik pembagian butiran: & \\
& - Pasir (\%) & 76 \\
& - Lanau (\%) & 10 \\
& - Lempung (\%) & 14 \\
5 & Batas cair, LL (\%) & 35,20 \\
6 & Batas plastis, PL (\%) & 25,06 \\
7 & Indeks plastisitas, PI (\%) & 10,14 \\
\hline
\end{tabular}

Jenis tanah ditentukan menurut klasifikasi sistem USCS (Unified Soil Classification System) yang berdasarkan data Tabel 1, maka digunakan simbol kelompok SC yaitu tanah jenis pasir berlempung.

\section{Hasil Pengujian Triaksial UU}

Pengujian dilakukan menurut lama pemeraman dengan beberapa variasi kadar semen. Hasil pengujian triaksial UU disajikan dalam Tabel 2.

Tabel 2. Hasil pengujian Triaksial UU

\begin{tabular}{|c|c|c|c|c|c|c|c|c|}
\hline \multirow{4}{*}{$\begin{array}{c}\text { Pemer } \\
\text { aman } \\
\text { (hari) }\end{array}$} & \multicolumn{8}{|c|}{ Variasi Benda Uji } \\
\hline & \multicolumn{2}{|c|}{ Tanah } & \multicolumn{2}{|c|}{$\begin{array}{c}\text { Tanah + } \\
\text { 5\%Semen }\end{array}$} & \multicolumn{2}{|c|}{$\begin{array}{c}\text { Tanah+10\% Seme } \\
\text { n }\end{array}$} & \multicolumn{2}{|c|}{ Tanah+15\%Semen } \\
\hline & $c$ & & $c$ & & $c$ & $\phi$ & $c$ & $\phi$ \\
\hline & $\mathrm{kN} / \mathrm{m}$ & $\begin{array}{c}\text { (derajat } \\
\text { ) }\end{array}$ & $\mathrm{kN} / \mathrm{m}^{2}$ & $\begin{array}{c}\text { (derajat } \\
\text { ) }\end{array}$ & $\mathrm{kN} / \mathrm{m}^{2}$ & $\begin{array}{c}\text { (derajat } \\
\text { ) }\end{array}$ & $\mathrm{kN} / \mathrm{m}^{2}$ & (derajat) \\
\hline 0 & 27 & 29 & 48 & 28 & 165 & 21 & 219 & 23 \\
\hline 3 & - & - & 60 & 28 & 176 & 28 & 331 & 22 \\
\hline 7 & - & - & 97 & 25 & 197 & 35 & 414 & 18 \\
\hline 14 & - & - & 139 & 27 & 186 & 40 & 726 & 27 \\
\hline 28 & - & - & 91 & 39 & 112 & 49 & 711 & 29 \\
\hline
\end{tabular}


Hasil pengujian triaksial UU menunjukkan semakin lama umur pemeraman maka semakin meningkat kuat geser tanah, yang ditunjukkan dari peningkatan sudut geser $(\varphi)$, tetapi tidak untuk kohesi tanah yang hanya mencapai kekuatan puncak pada pemeraman 14 hari saja. Peningkatan kuat geser dipengaruhi oleh berkurangnya derajat kejenuhan benda uji. Dimana panas hidrasi semen membuat kadar air berkurang seiring lama pemeraman dan berkurangnya volume rongga karena membesarnya ukuran butir-butir tanah.

\section{Hasil Pengujian Tekan Bebas}

Dari kuat tekan bebas $\left(q_{\mathrm{u}}\right)$ maka dapat diperoleh kuat geser atau kohesi $\left(c_{\mathrm{u}}\right)$ yaitu seperdua kuat tekan bebas $c_{u}=1 / 2 q_{u}$. Hasil pengujian kuat tekan bebas dan kohesinya disajikan pada Tabel 3.

Tabel 3. Hasil pengujian tekan bebas

\begin{tabular}{|c|c|c|c|c|c|c|c|c|}
\hline \multirow{4}{*}{$\begin{array}{c}\text { Pemera } \\
\text { man } \\
\text { (hari) }\end{array}$} & \multicolumn{8}{|c|}{ Variasi Benda Uji } \\
\hline & \multicolumn{2}{|c|}{ Tanah } & \multicolumn{2}{|c|}{ Tanah $+5 \%$ Semen } & \multicolumn{2}{|c|}{$\begin{array}{c}\text { Tanah }+10 \% \\
\text { Semen }\end{array}$} & \multicolumn{2}{|c|}{$\begin{array}{l}\text { Tanah }+15 \% \\
\text { Semen }\end{array}$} \\
\hline & $q_{\mathrm{u}}$ & $s_{\mathrm{u}}=c_{\mathrm{u}}$ & $q_{\mathrm{u}}$ & $s_{\mathrm{u}}=c_{\mathrm{u}}$ & $q_{\mathrm{u}}$ & $s_{\mathrm{u}}=c_{\mathrm{u}}$ & $q_{\mathrm{u}}$ & $s_{\mathrm{u}}=c_{\mathrm{u}}$ \\
\hline & $\mathrm{kN} / \mathrm{m}^{2}$ & $\mathrm{kN} / \mathrm{m}^{2}$ & $\mathrm{kN} / \mathrm{m}^{2}$ & $\mathrm{kN} / \mathrm{m}^{2}$ & $\mathrm{kN} / \mathrm{m}^{2}$ & $\mathrm{kN} / \mathrm{m}^{2}$ & $\mathrm{kN} / \mathrm{m}^{2}$ & $\mathrm{kN} / \mathrm{m}^{2}$ \\
\hline 0 & 109,1 & 54,5 & 140,4 & 70,2 & 576,4 & 288,2 & 602,6 & 301,3 \\
\hline 3 & - & - & 193,0 & 96,5 & 663,9 & 332,0 & 824,8 & 412,4 \\
\hline 7 & - & - & 369,4 & 184,7 & 857,2 & 428,6 & 1111,0 & 555,5 \\
\hline 14 & - & - & 538,6 & 269,3 & 1184,7 & 592,3 & 1499,6 & 749,8 \\
\hline 28 & - & - & 849,3 & 424,7 & 1234,5 & 617,2 & 1956,2 & 978,1 \\
\hline
\end{tabular}

meningkat seiring bertambahnya lama pemeraman dan kadar semen. Hal ini menunjukkan bahwa semen mampu meningkatkan kekuatan tanah dengan cara mengikat butir-butir tanah sehingga tanah menjadi padat dan keras.

\section{Perbandingan Hasil Pengujian Triaksial UU dan Program Plaxis2D}

Perbandingan antara tegangan regangan pengujian triaksial UU dan program Plaxis $2 D$ model Mohr-Coulumb dan Hardening Soil untuk tanah asli pada 0 hari pemeraman dari tekanan sel $\left(\sigma_{3}\right) 50 ; 100 ; 200 \mathrm{kN} / \mathrm{m}^{2}$ yang disajikan dalam bentuk kurva sebagai berikut.

a. Tekanan sel $50 \mathrm{kN} / \mathrm{m}^{2}$

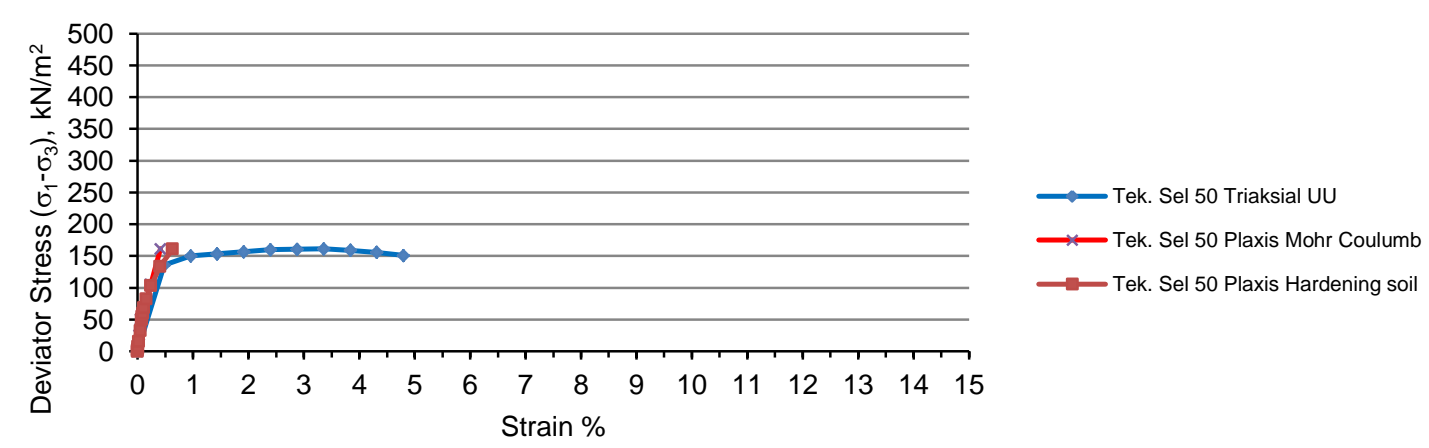

Gambar 4. Grafik perbandingan tegangan regangan tanah asli dengan tekanan sel $50 \mathrm{kN} / \mathrm{m}^{2}$ 
Dari Gambar 4 dapat dijelaskan bahwa analisis program Plaxis 2D model Mohr-Coulumb dan Hardening Soil memberikan hasil tegangan puncak yang mendekati sama dengan hasil pengujian triaksial UU yaitu sebesar $161,2 \mathrm{kN} / \mathrm{m}^{2}$, tetapi dengan regangan yang berbeda-beda. Untuk model Mohr-Coulumb diperoleh regangan sebesar 0,41\%, regangan model Hardening Soil sebesar 0,63\% dan regangan pengujian triaksial UU sebesar 3,36\%. Regangan model MohrCoulumb lebih kecil dari model Hardening Soil dan pengujian triaksial UU. Artinya analisis dengan model Mohr-Coulumb, keruntuhan benda uji lebih dahulu tercapai. Berbeda untuk model Hardening Soil dengan regangan yang lebih besar dari model Mohr-Coulumb karena merupakan model tingkat lanjut untuk memodelkan perilaku tanah yang keras dan bentuk kemiringan kurva yang mendekati pengujian triaksial UU.

b. Tekanan sel $100 \mathrm{kN} / \mathrm{m}^{2}$

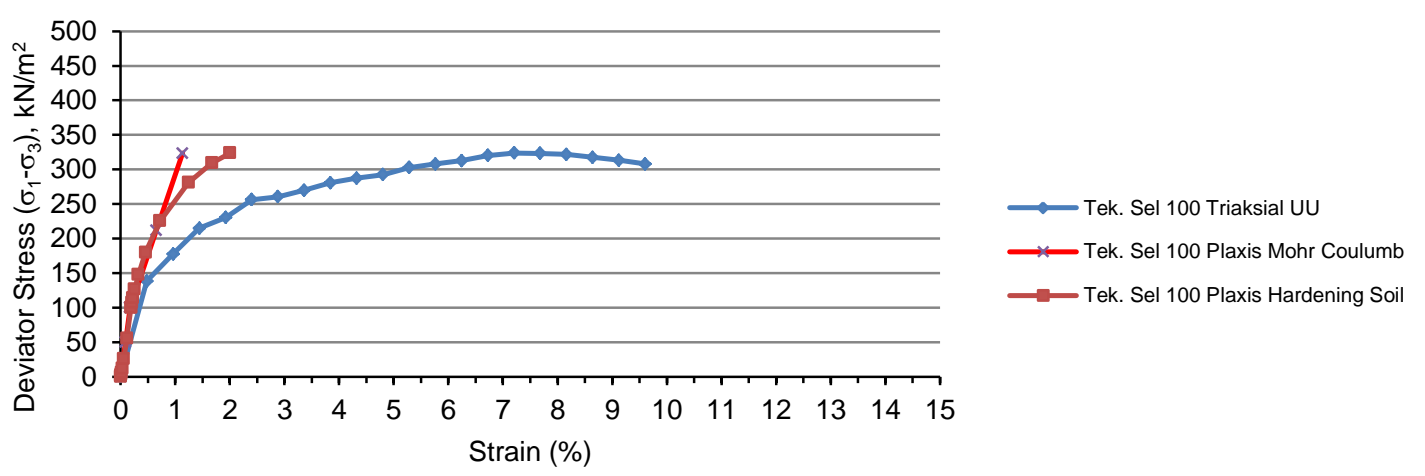

Gambar 5. Grafik perbandingan tegangan regangan tanah asli dengan tekanan sel 100 $\mathrm{kN} / \mathrm{m}^{2}$

Dari Gambar 5 dapat dijelaskan bahwa model Mohr-Coulumb dan Hardening Soil memberikan hasil tegangan puncak yang mendekati sama dengan hasil pengujian triaksial UU yaitu sebesar $323,7 \mathrm{kN} / \mathrm{m}^{2}$, tetapi dengan regangan yang berbeda-beda. Regangan model MohrCoulumb lebih kecil dari model Hardening Soil dan pengujian triaksial UU. Artinya analisis dengan model Mohr-Coulumb, keruntuhan benda uji lebih dahulu tercapai.

Berbeda untuk model Hardening Soil dengan regangan yang lebih besar dari model MohrCoulumb karena merupakan model tingkat lanjut untuk memodelkan perilaku tanah yang keras dan bentuk kemiringan kurva yang mendekati pengujian triaksial UU.

c. Tekanan sel $200 \mathrm{kN} / \mathrm{m}^{2}$ 


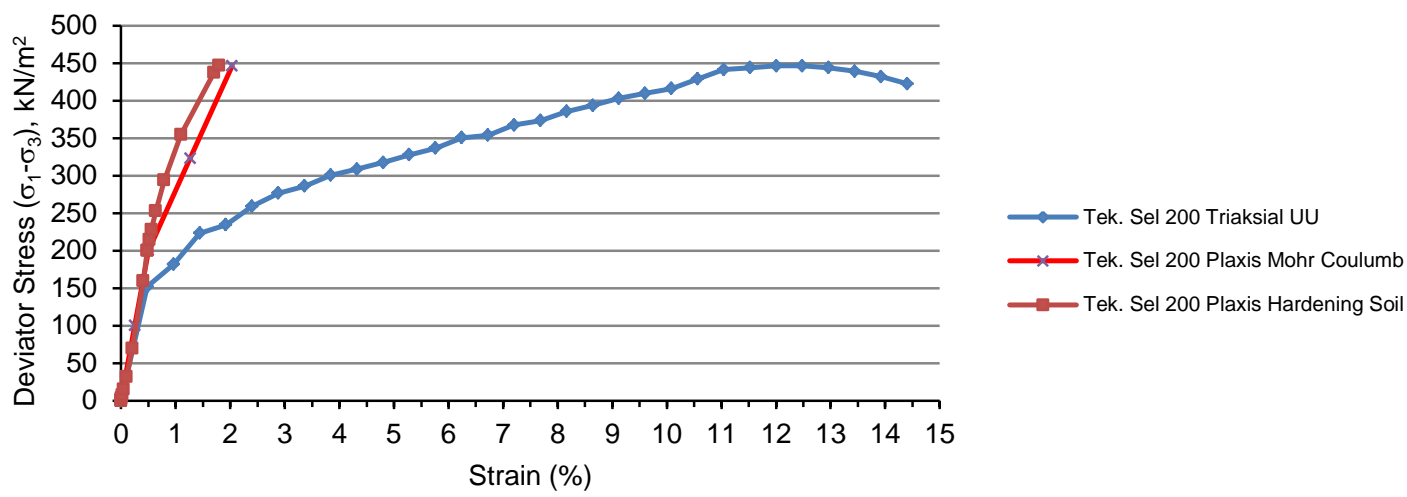

Gambar 6. Grafik perbandingan tegangan regangan tanah asli untuk lama pemeraman 0 hari dengan tekanan sel $200 \mathrm{kN} / \mathrm{m}^{2}$

Dari Gambar 6 dapat dijelaskan bahwa model Mohr-Coulumb memberikan hasil tegangan puncak yang mendekati sama dengan hasil pengujian triaksial UU dengan regangan yang berbeda-beda. Regangan model Hardening Soil lebih kecil dari model Mohr-Coulumb dan pengujian triaksial UU. Artinya analisis dengan model Hardening Soil, keruntuhan benda uji lebih dahulu tercapai. Hal ini terjadi karena tekanan sel $\left(\sigma_{3}\right)$ sebesar $200 \mathrm{kN} / \mathrm{m}^{2}$ memberikan pengaruh terhadap benda uji sehingga lebih dahulu mencapai keruntuhan. Berbeda dengan pemberian tekanan sel sebelumnya dalam Gambar 4 dan 5 yaitu pemberian tekanan sel 50 $\mathrm{kN} / \mathrm{m}^{2}$ dan $100 \mathrm{kN} / \mathrm{m}^{2}$, hasil regangan model Hardening Soil selalu lebih besar dari model Mohr-Coulumb.

\section{Perbandingan Hasil Pengujian Tekan Bebas dan Program Plaxis 2D}

Perbandingan antara tegangan regangan pengujian tekan bebas dan Plaxis 2D model MohrCoulumb dan Hardening Soil untuk tanah asli 0 hari pemeraman dapat dilihat pada Gambar 7.

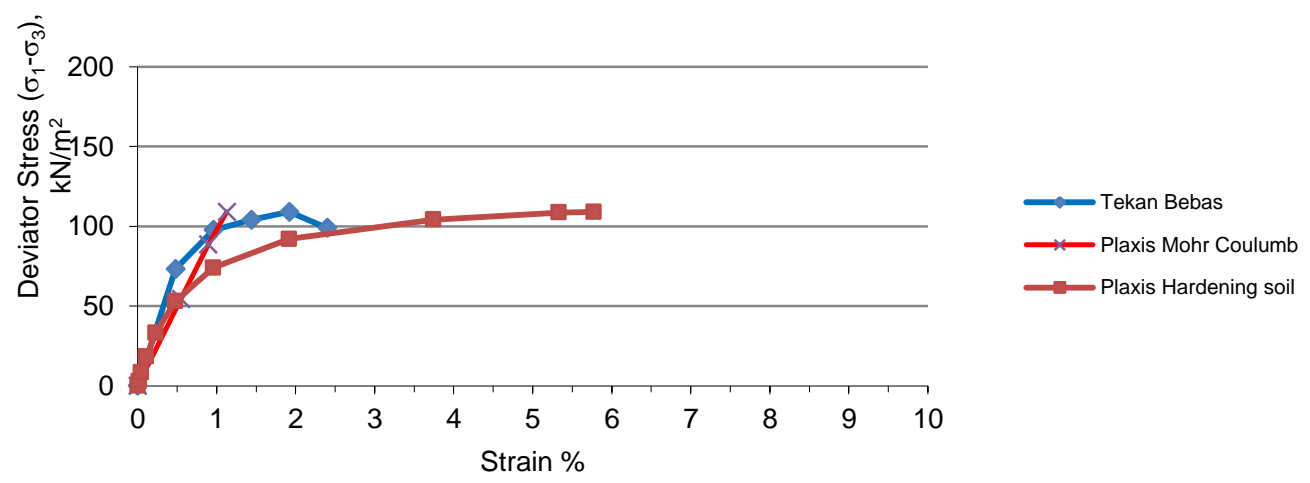

Gambar 7. Grafik perbandingan tegangan regangan tanah asli

Dari Gambar 7 dapat dijelaskan bahwa model Mohr-Coulumb dan Hardening Soil memberikan hasil tegangan puncak yang mendekati sama dengan hasil pengujian tekan bebas, tetapi dengan regangan yang berbeda-beda. Regangan model Mohr-Coulumb selalu lebih kecil 
dari model Hardening Soil dan pengujian tekan bebas. Artinya analisis dengan model MohrCoulumb, memberikan keruntuhan benda uji lebih dahulu tercapai.

Berbeda untuk model Hardening Soil dengan hasil regangan yang lebih besar dari model Mohr-Coulumb dan tekan bebas karena merupakan model tingkat lanjut untuk memodelkan perilaku tanah yang keras sehingga proses analisis memerlukan waktu yang lebih lama untuk mencapai tegangan puncak. Begitu juga kemiringan kurva model Hardening Soil yang berbentuk hiperbolik mendekati pengujian tekan bebas, sedangkan kurva model Mohr-Coulumb berbentuk linear.

\section{SIMPULAN}

1. Bahan semen mampu meningkatkan kuat geser tanah

2. Berdasarkan analisis balik dalam program Plaxis2D, bahwa model Hardening Soil dan Mohr-Coulumb memberikan hasil tegangan deviator yang mendekati sama dengan hasil pengujian triaksial UU dan tekan bebas.

3. Analisis balik program Plaxis2D dengan model Mohr-Coulumb, memberikan hasil regangan yang lebih kecil dari pengujian triaksial UU dan tekan bebas. Dengan model Hardening Soil, memberikan hasil regangan yang fluktuatif dari pengujian triaksial UU karena dipengaruhi oleh penerapan tekanan sel $\left(\sigma_{3}\right)$ dan memberikan hasil regangan yang lebih besar dari pengujian tekan bebas.

\section{DAFTAR PUSTAKA}

Hardiyatmo, H. C., 2012, Mekanika Tanah 1, Cetakan pertama, Edisi keenam, Penerbit Gadjah Mada University Press, Yogyakarta.

Schanz,T., 2004, "Non-Linear Hyperbolic Model \& Parameter Selection", Course on Computational Geotechnics, Bauhaus-Universitat Weimar, Germany (08 April 2016) http://ceae.colorado.edu/ sture/plaxis/slides/Course\%20Notes\%20on\%20Nonlinear\%20Hy perbolic\%20Mode1\%20and\%20Parameter\%20 Selection.doc

Tarigan, R., 2012, Karakteristik Kuat Geser Tanah Lempung Dari Uji Unconfined Compressive Strenght dan Uji Triaksial Takterkonsolidasi Takterdrainase, Tesis Magister, Program Studi Teknik Sipil Program Pasca Sarjana Universitas Sumatera Utara, Medan 